\title{
Combined Functional and Immunochemical Analysis of Normal and Abnormal Human Factor X
}

\author{
Daryl S. Fair, Edward F. Plow, and Thomas S. Edgington, Department of \\ Molecular Immunology, The Research Institute of Scripps Clinic, La Jolla, \\ California 92037
}

A B S T R A C T Human Factor $\mathrm{X}$ was isolated from Cohn fraction III and characterized by polyacrylamide gel electrophoresis, amino acid composition, and isoelectric focusing. Two molecular forms with biological activity were observed at isoelectric points of 4.8 and 5.0. Antisera generated to Factor $X$ was monospecific and used to establish an equilibrium competitive inhibition radioimmunoassay. This assay was specific for human Factor $\mathrm{X}$ and did not cross-react with human prothrombin or bovine Factor $\mathrm{X}$ within the sensitivity range of 6-300 $\mathrm{ng}$ Factor $\mathrm{X}$ antigen $/ \mathrm{ml}$. The mean concentration of Factor $\mathrm{X}$ based on the antigen was $11.9 \mu \mathrm{g} / \mathrm{ml}$, whereas concentration values based on coagulant activity was $7.8 \mu \mathrm{g} / \mathrm{ml}$. This $30 \%$ difference in measurement appears to result from the presence of a subpopulation of Factor $\mathrm{X}$ molecules devoid of coagulant activity. The radioimmunoassay was used to qualitatively and quantitatively compare purified Factor $\mathrm{X}$ to plasmic Factor $\mathrm{X}$ obtained from normal, warfarintreated, acquired Factor X-deficient, and congenitaldeficient patients. In all but one case, the Factor $X$ present in these plasmas was immunochemically identical to the purified Factor $\mathrm{X}$ and permitted precise quantitation of these abnormal Factor $\mathrm{X}$ molecules. Factor $\mathrm{X}$ procoagulant activity was analyzed relative to Factor $X$ antigen and the specific activities were used to characterize normal and abnormal Factor X molecules. Reduced Factor X activity in plasmas from warfarin-treated and acquired Factor Xdeficient patients was attributed to both decreases in Factor $\mathrm{X}$ antigen and decreased function of the Factor X molecules. Congenitally deficient patients, in general, showed a reduction in Factor $\mathrm{X}$ antigen in parallel with Factor $\mathrm{X}$ procoagulant activities

This is publication 1688 of the Research Institute, and was presented in part at the meeting of the American Society of Biological Chemists 4-8 June 1978 in Atlanta, Ga.

Dr. Plow is an Established Investigator of the American Heart Association.

Received for publication 19 January 1979 and in revised form 14 May 1979. resulting from comparable decreases in specific biological activity of the molecules.

\section{INTRODUCTION}

Plasma Factor $\mathrm{X}$ occupies a pivotal position in the blood coagulation scheme and, as such, its activation and function are of central importance in the study of thrombotic and hemostatic diseases. Factor $\mathrm{X}$ is the point of interface for both the intrinsic and extrinsic procoagulant pathways and is the substrate zymogen for these proteolytic activation complexes. The active enzyme, Factor Xa, initiates the late stage of blood coagulation by cleavage of prothrombin to form thrombin (1). Although bovine Factor $\mathrm{X}$ has been extensively investigated, isolation of Factor $\mathrm{X}$ from human plasma has only recently been described (2-6). Human Factor X, a glycoprotein, has an estimated mol wt of 59,000 with $15 \%$ carbohydrate and consists of a disulfide-linked 42,000-mol wt heavy chain and 17,000-mol wt light chain (2). The activation of Factor $\mathrm{X}$ and subsequent proteolytic cleavages of prothrombin is supported by phospholipid membranes and calcium. These events are mediated through the gamma carboxylated glutamic acid residues located on the amino terminal of the light chain of this vitamin K-dependent protein (1).

Most clinical studies of Factor X have been limited to biological clotting assays which utilize congenital Factor X-deficient plasma or bovine plasma artificially depleted of Factor $X$. In a few studies antisera with specificity to Factor $X$ have been used to immunologically estimate the presence of Factor $\mathrm{X}$ protein $(7-15)$. Whereas qualitative assessment has employed immunoelectrophoresis $(9,11,12)$, quantitation of Factor $\mathrm{X}$ antigen has been attempted by antibody neutralization $(7,8,10)$, and radioimmunoassay $(14,15)$. The latter method has been described for bovine (14) and canine (15) but not human Factor X.

Factor X molecules known or presumed to be abnormal have been described in congenital and in 
aquired deficiencies. Congenital Factor X deficiency has been characterized as an incompletely recessive autosomal trait $(11,16)$; and unrelated individuals afflicted with this disorder presumably represent a variety of abnormalities at different points in the molecule giving rise to a spectrum of biological activities and variable concentrations of plasma Factor X (7). Acquired Factor X deficiency independent of vitamin $\mathrm{K}$ deficiency is a rare coagulation defect in which the majority of cases described have been associated with amyloidosis (17-19). Radiolabeled Factor $\mathrm{X}$ injected into these patients was rapidly cleared from the plasma (18) and shown to bind more readily to amyloid fibrils isolated from one patient with this coagulation disorder (19). Although the Factor $X$ of the patients was assumed to be normal, this has not been investigated. Finally, individuals undergoing anticoagulant therapy with pheninidione or warfarin have been reported to have a decrease in Factor $\mathrm{X}$ coagulant activity relative to Factor $X$ antigen $(8,12)$. This decrease in the ratio of activity to antigen could reflect the synthesis of biologically inactive molecules lacking the posttranslational carboxylation of specific glutamic acid residues implicated in the calciumdependent interaction of Factor $\mathrm{X}$ with phospholipid(1).

In the present investigation, we describe the isolation of highly purified human Factor $\mathrm{X}$ from Cohn fraction III, the development of a radioimmunoassay specific for the intact molecule, and the quantitation of Factor $\mathrm{X}$ antigen and activity in plasma from normal, Factor X-deficient and warfarintreated patients.

\section{METHODS}

Materials. Acrylamide, $N, N^{\prime}$-methylenebisacrylamide, hydroxylapatite, and sodium dodecyl sulfate $(\mathrm{SDS})^{1}$ were obtained from Bio-Rad Laboratories, Richmond, Calif. Bovine Factor VII-X-deficient plasma, Russell's viper venom, rabbit brain cephalin, disodium EDTA, Coomassie Brilliant Blue R, Coomassie Blue G-250, Sigma 7-9, $\epsilon$-aminocaproic acid, heparin sodium salt grade I (150 USP U/mg), morpholinoethanesulfonic acid, poly-L-lysine (type I-B) and $p$-aminobenzamidine hydrochloride were purchased from Sigma Chemical Co., St. Louis, Mo. Barium chloride, ammonium sulfate, sodium citrate, chloramine $\mathrm{T}$, and sodium metabisulfite were obtained from J. T. Baker Chemical Co., Phillipsburg, N. J. Sephadex G-25, G-50, G-100, and Sepharose 2B were bought from Pharmacia Fine Chemicals, Div. of Pharmacia Inc., N. J. Kaolin was a product of Fisher Scientific Co., Pittsburgh, Pa. Cyclohexylmorpholinoethylcarbodiimide and $O$-methylisourea were obtained from Aldrich Chemical Co., Milwaukee, Wisc. Benzamidine and phenylmethylsulfonyl fluoride were purchased from Calbiochem-Behring Corp., American Hoechst Corp., San Diego, Calif. Sodium azide was a product of Mallinckrodt Inc., St. Louis, Mo. DEAE-cellulose (DEAE-52) was obtained from

${ }^{1}$ Abbreviations used in this paper: $r$, correlation coefficient; RVV, Russell's viper venom; SDS, sodium dodecyl sulfate.
Whatman Inc., Clifton, N. J. ${ }^{125} \mathrm{I}-\mathrm{Na}(50 \mathrm{mCi} / \mathrm{ml})$ was purchased from Amersham Corp., Arlington Heights, Ill. Trasylol was a product of FBA Pharmaceuticals, New York. Brain thromboplastin was obtained from Ortho Pharmaceutical Corp., Raritan, N. J. Nobel agar was a product of Difco Laboratories, Detroit, Mich. Ampholytes were purchased from LKB Instruments, Inc., Rockville, Md. Human Factor X-deficient plasma was obtained from George King Biomedical, Inc., Overland Park, Kans. Benzamidine-Sepharose 2B was constructed by the method of Schmer (20) as modified by DiScipio et al. (2). Homoarginine-Sepharose 2B was prepared by the procedures of Kimmel (21) and DiScipio et al. (2).

Plasma samples. Normal plasma samples and plasma from patients were collected in citrate-phosphate-dextrose or $2.9 \%$ sodium citrate. Many of the Factor X-deficient plasmas were the generous gifts of Doctors H. L. Nossel, B. Furie, J. B. Graham, A. L. Bloom, S. Lemkin, J. Baker, and Y. Sultan. Some of these plasmas arrived in a lyophilized state which under appropriate conditions we had shown did not affect the procoagulant activity or antigenic structure of Factor X.

Coagulation tests. Assays for Factor $\mathrm{X}$ during isolation employed the use of Russell's viper venom (RVV) according to the method of Bachmann et al. (22). In addition to this method, normal, warfarin-treated and Factor X-deficient plasma were assayed for extrinsic activation by the one-stage prothrombin time using human Factor X-deficient plasma and for intrinsic activation by the kaolin-cephalin clotting time employing Factor X-deficient human plasma as the substrate plasma (23). All values represent the mean of triplicate determinations and have been normalized to a pool of 26 normal donors.

Isolation of human Factor $X$. All isolation procedures were carried out at $4^{\circ} \mathrm{C}$ to minimize activation, and Factor $X$ activity and antigen (antisera kindly provided by Dr. D. Aronson) were monitored. Several of the steps were modified from previously described procedures $(2,3)$. $1 \mathrm{~kg}$ of Cohn fraction III (generously supplied by Dr. M. Hrinda of Armour Pharmaceutical Company, Phoenix, Ariz.) was extracted in 15 liters of $0.01 \mathrm{M}$ Tris- $\mathrm{HCl}, \mathrm{pH} 9.0$, $0.025 \mathrm{M}$ sodium citrate, $0.15 \mathrm{M}$ sodium chloride, $2 \mathrm{mM}$ benzamidine, $15,000 \mathrm{U}$ heparin for $1 \mathrm{~h}$. The solution was clarified by centrifugation at $1,500 \mathrm{~g}$ for $20 \mathrm{~min}$. To the supernate was added drop-wise 1.05 liters of $1 \mathrm{M}$ barium chloride, and after mixing for 15 min the precipitate was collected by centrifugation at $1,500 \mathrm{~g}$ for $20 \mathrm{~min}$. Proteins absorbed to the barium citrate pellet were washed twice with water and then eluted into 3 liters of $0.05 \mathrm{M}$ morpholinoethanesulfonic acid- $\mathrm{HCl}(\mathrm{pH} 5.85)$ containing $0.2 \mathrm{M}$ sodium citrate, $0.01 \mathrm{M}$ benzamidine, 3,000 $\mathrm{U}$ heparin overnight. After centrifugation at $10,000 \mathrm{~g}$ for $20 \mathrm{~min}$, solid ammonium sulfate was added to the pooled supernates to $40 \%$ saturation and mixed for $30 \mathrm{~min}$. After centrifugation the resulting supernate was adjusted to $70 \%$ saturation with solid ammonium sulfate, mixed for $\mathbf{4 5} \mathrm{min}$, and then centrifuged at $10,000 \mathrm{~g}$ for $20 \mathrm{~min}$. The pellet was dissolved in a minimal volume of $0.02 \mathrm{M}$ Tris- $\mathrm{NaOH}, \mathrm{pH} 5.85,0.1 \mathrm{M}$ EDTA, $2 \mathrm{mM}$ benzamidine, $0.02 \%$ sodium azide, and then dialyzed overnight against 1 liter of this buffer. After dialysis against 1 liter of $0.02 \mathrm{M}$ Tris $-\mathrm{H}_{3} \mathrm{PO}_{4}$ ( $\mathrm{pH} 5.85$ ) containing $2 \mathrm{mM}$ benzamidine, $0.02 \%$ sodium azide with two changes, the protein was applied to a DEAE-cellulose column $(5 \times 28 \mathrm{~cm})$ equilibrated in this buffer. The protein was eluted over $48 \mathrm{~h}$ with a linear gradient from 0.10 to $0.35 \mathrm{M} \mathrm{NaCl}$ in the initial buffer at $55 \mathrm{ml} / \mathrm{h}$. After concentration and dialysis against 1 liter of $0.15 \mathrm{M}$ potassium phosphate $\mathrm{pH} 6.8$ containing $1 \mathrm{mM}$ benzamidine, $0.02 \%$ sodium azide with one change, the protein solution was applied to a hydroxylapatiteSephadex G-25 (1:1 vol/vol) column $(2.5 \times 45 \mathrm{~cm})$ equilibrated in 
this same buffer. Factor $\mathrm{X}$ was eluted from the column over $48 \mathrm{~h}$ with a linear gradient from 0.15 to $0.30 \mathrm{M}$ potassium phosphate, pH 6.8 , containing $1 \mathrm{mM}$ benzamidine, $0.02 \%$ sodium azide at $16 \mathrm{ml} / \mathrm{h}$. After concentration and dialysis against $0.05 \mathrm{M}$ morpholinoethanesulfonic acid-Tris $\mathrm{pH} 5.85$ containing $2 \mathrm{mM}$ benzamidine, $0.02 \%$ sodium azide, the protein was applied to a benzamidine-Sepharose column $(1.6 \times 23 \mathrm{~cm})$ equilibrated in this buffer, and eluted over $24 \mathrm{~h}$ using a linear gradient from 0.1 to $0.4 \mathrm{M} \mathrm{NaCl}$ at $17 \mathrm{ml} / \mathrm{h}$. The Factor X-containing peak was chromatographed on a homoarginine-Sepharose column $(1.6 \times 20 \mathrm{~cm})$ equilibrated in $0.02 \mathrm{M}$ morpholinoethanesulfonic acid-Tris pH 5.85, $0.02 \%$ sodium azide, and a 24 -h linear gradient from 0.2 to $2 \mathrm{M} \mathrm{NaCl}$ in this buffer was developed at $14 \mathrm{ml} / \mathrm{h}$. After concentrating, the Factor $\mathrm{X}$ protein was chromatographed on Sephadex G-100 $(2.5 \times 90 \mathrm{~cm})$ equilibrated $0.01 \mathrm{M}$ potassium phosphate, $\mathrm{pH} 6.0$ containing $0.14 \mathrm{NaCl}, 0.02 \%$ sodium azide, at $14 \mathrm{ml} / \mathrm{h}$. The Factor $\mathrm{X}$ eluting from this column showed a constant specific activity over the protein profile and was concentrated and stored at $-70^{\circ} \mathrm{C}$. Some samples also contained $10 \mathrm{mM}$ benzamidine.

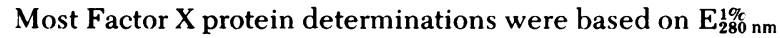
$=11.6$ (2). The concentration of standard Factor $\mathrm{X}$ was established from the amino acid composition.

Gel electrophoresis. Analytical polyacrylamide gels were carried out at alkaline $\mathrm{pH}$ according to Davis (24) and SDS-polyacrylamide gel electrophoresis was employed at neutral $\mathrm{pH}(25)$ and at alkaline $\mathrm{pH}$ (26). Protein bands were developed with freshly prepared Coomassie Brilliant Blue $\mathrm{R}$ according to the procedure of Weber and Osborn (25). Isoelectric focusing was performed with a pH gradient between 3 and 8 as described by Righetti and Drysdale (27) and stained with Coomassie Blue G-250 according to the procedure of Reisner et al. (28). Molecular weight standards used in the SDS-polyacrylamide gel electrophoresis were the $\mathrm{A} \alpha-, \mathrm{B} \beta-$, and $\gamma$-chain of fibrinogen $(63,500,56,000$, and 47,000 , respectively), bovine serum albumin $(68,000)$, ovalbumin $(43,000)$, chymotrypsinogen $(25,000)$, and myoglobin $(17,000)$.

Amino acid compositions. Samples were hydrolyzed for $24 \mathrm{~h}$ in $6.0 \mathrm{~N} \mathrm{HCl}$ in evacuated tubes at $110^{\circ} \mathrm{C}$. Analyses were performed on a Beckman $121 \mathrm{M}$ automated amino acid analyzer (Beckman Instruments, Inc., Fullerton, Calif.) using the two-column procedure. Values represent the mean of duplicate determinations, and a mol wt of 50,355 was adapted for the protein portion of human Factor $\mathrm{X}$ as determined by DiScipio et al (2) for purposes of calculation.

Antisera. Two New Zealand white female rabbits were injected with $39 \mu \mathrm{g}$ of purified Factor X emulsified in Freund's complete adjuvant at multiple subcutaneous sites. The animals were boosted with $20 \mu \mathrm{g}$ of protein emulsified in Freund's incomplete adjuvant every $3 \mathrm{wk}$. After the third boost, antisera were judged to be of relative high titer and employed in these studies.

Antibody neutralization. These studies utilized either normal rabbit serum or rabbit antiserum to human Factor $\mathrm{X}$ which had been absorbed with barium sulfate $(100 \mathrm{mg} / \mathrm{ml})$ and heat inactivated $\left(56^{\circ} \mathrm{C}\right.$ for $\left.40 \mathrm{~min}\right)$. The sera were diluted in $0.025 \mathrm{M}$ barbital pH 7.4 containing $0.125 \mathrm{M} \mathrm{NaCl}$ and $0.1 \%$ sodium azide. To $1 \mathrm{ml}$ of a $1 / 1$ oth dilution of normal human plasma was added $1.0 \mathrm{ml}$ of diluted antiserum or normal serum. After incubation for $24 \mathrm{~h}$ at $4^{\circ} \mathrm{C}$ the solution was tested for Factor X activity.

Immunoelectrophoresis was carried out on $1 \times 3$-inch slides overlayered with $3 \mathrm{ml}$ of $1 \%$ Nobel agar in $0.04 \mathrm{M}$ barbital, pH 8.2. Electrophoresis was carried out at $5 \mathrm{~mA} /$ slide for $105 \mathrm{~min}$. After addition of antiserum to the trough, the reaction was developed at room temperature for $24 \mathrm{~h}$.
Radioiodination. Factor $\mathrm{X}$ was labeled with ${ }^{125} \mathrm{I}-\mathrm{Na}$ by a modification of the chloramine $T$ procedure (29). Factor $X$ $(20 \mu \mathrm{g})$ was mixed with $0.5 \mathrm{M}$ potassium phosphate $\mathrm{pH} 7.2$ to a final volume of $100 \mu \mathrm{l}$. To this was added $10 \mu \mathrm{l}$ of ${ }^{125} \mathrm{I}-\mathrm{Na}(50 \mathrm{mCi} / \mathrm{ml})$ and $10 \mu \mathrm{l}$ of chloramine $\mathrm{T}$ in phosphatebuffered saline $(300 \mu \mathrm{g} / \mathrm{ml})$ and reacted for $2 \mathrm{~min}$ with constant agitation. Sodium metabisulfite in phosphate-buffered saline ( $10 \mu \mathrm{l}$ of a $300-\mu \mathrm{g} / \mathrm{ml}$ solution) was added to terminate labeling. After mixing for $30 \mathrm{~s}, 100 \mu \mathrm{l}$ of $2 \%$ potassium iodide and $100 \mu \mathrm{l} 1 \%$ bovine serum albumin in phosphatebuffered saline were added. Iodinated Factor $X$ was isolated by chromatography on a $12-\mathrm{ml}$ column of Sephadex G-50 equilibrated with $1 \%$ bovine serum albumin, $0.1 \%$ sodium azide in phosphate-buffered saline. The radiolabeled Factor $\mathrm{X}$ was $94-97 \%$ precipitable by $10 \%$ trichloroacetic acid.

Radioimmunoassay. The equilibrium competitive inhibition radioimmunoassay for Factor $\mathrm{X}$ was carried out with a four compartment procedure. To: (a) $0.5 \mathrm{ml}$ of labeled Factor X $(0.1$ or $0.05 \mathrm{nM})$ was added, (b) $0.5 \mathrm{ml}$ of buffer, dilution of competing antigen or plasma, and $(c) 0.5 \mathrm{ml}$ of diluted rabbit anti-Factor $\mathrm{X}$ antiserum. After $18 \mathrm{~h}$ at $4^{\circ} \mathrm{C}$, (d) $0.5 \mathrm{ml}$ of goat anti-rabbit IgG in slight antibody excess was added. After incubation for $6 \mathrm{~h}$ at $4^{\circ} \mathrm{C}$, the immunoprecipitate was sedimented at $2,500 \mathrm{rpm}$ for $20 \mathrm{~min}$ and $1.0 \mathrm{ml}$ of the supernate was collected, counted, and the binding was calculated. Statistical analysis of the data was handled according to Rodbard (30). The coefficient of variation within assays was $1-4 \%$ and between assays $2.9-10.6 \%$.

The buffer utilized in the assay and for all dilutions was $0.042 \mathrm{M}$ borate buffer, $\mathrm{pH} 8.3$ containing $0.025 \mathrm{M} \mathrm{NaCl}$, normal rabbit serum (1:50), $2 \mathrm{mM}$ benzamidine, $100 \mathrm{U} / \mathrm{ml}$ Trasylol and $1 \mathrm{mM}$ phenylmethylsulfonyl fluoride. All sera were heat inactivated.

\section{RESULTS}

Human Factor X of high purity was isolated from Cohn fraction III by the sequence summarized in Table I. From $1 \mathrm{~kg}$ of Cohn fraction III paste $528 \mathrm{~g}$ of protein was solubilized. A loss of $50 \%$ of Factor X occurred upon elution from barium citrate, but subsequent steps gave high yields with a final recovery of $20 \%$ of the solubilized Factor $\mathrm{X}$ at nearly 6,000-fold purification based on activity and antigen assays. The Factor $\mathrm{X}$ was devoid of $\mathrm{Xa}(<0.03 \%)$ by coagulant assay lacking $\mathrm{RVV}$, and the specific activity was $128 \mathrm{U} / \mathrm{mg}$, in good agreement with specific activities reported by others $(2,6)$.

The isolated Factor X was devoid of Xa or other plasma proteins as determined by polyacrylamide gel in SDS and disc gel electrophoresis (Fig. 1). On unreduced SDS gels only a single band was observed migrating with an apparent mol wt of 64,000 . Upon reduction two polypeptide chains were detected chains with estimated mol wt of 46,000 and 17,000 , respectively. The observed molecular weights were similar to values described for Factor $\mathrm{X}$ isolated from plasma $(2,6)$. The amino acid composition of human Factor $\mathrm{X}$ (Table II) was comparable to that reported by DiScipio et al. (2).

Isoelectric focusing of Factor $\mathrm{X}$ in ampholyte containing gels with a pH 3-8 linear gradient resolved 
TABLE I

Purification of Human Factor X from Cohn Fraction III

\begin{tabular}{|c|c|c|c|c|c|c|}
\hline Purification step & Volume & Total protein $*$ & Total activity & sp act & Recovery & Purification \\
\hline Tris-citrate extraction & 15,000 & 528,000 & 11,460 & 0.022 & 100.0 & \\
\hline Ammonium sulfate $(40-70 \%)$ & 192 & 4,493 & 4,904 & 1.09 & 42.8 & 50.2 \\
\hline DEAE-cellulose & 46 & 3,487 & 3,926 & 1.13 & 34.3 & 52.1 \\
\hline Homoarginine-Sepharose & 60.9 & 36.8 & 2,573 & 69.9 & 22.5 & 3,221 \\
\hline Sephadex G-100 & 16.9 & 18.6 & 2,383 & 128.0 & 20.8 & 5,897 \\
\hline
\end{tabular}

* Protein concentrations were determined by absorbance at $280 \mathrm{~nm}$ and assumed $\mathrm{E}_{280 \mathrm{~nm}}^{1 \%}$ of 11.6 (2).

f A unit of Factor $\mathrm{X}$ is defined as the activity present in $1 \mathrm{ml}$ of pooled normal human plasma.

two discrete bands with pIs of 4.8 and 5.0 (Fig. 1). When gels were sliced and the protein eluted, Factor X coagulant activity was coincident with both protein bands, suggesting that human Factor $\mathrm{X}$ exists in two distinct charge forms similar to that observed for the bovine molecule $(31,32)$.

Rabbit antisera to Factor $\mathrm{X}$ were monospecific by immunoelectrophoresis, producing only a single precipitin arc with the purified molecule as well as with barium citrate concentrates of normal human plasma. Further, $1 \mathrm{ml}$ of these antiserum had the capacity to completely neutralize the Factor $\mathrm{X}$ coagulant activity of $22 \mathrm{ml}$ of normal human plasma.

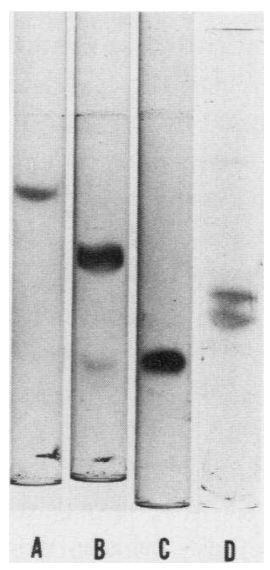

Figure 1 PAGE analysis of purified human Factor X. (A) Migration of $8 \mu \mathrm{g}$ of Factor $\mathrm{X}$ in Laemmli (26) gels containing $10 \%$ acrylamide, $0.1 \%$ SDS (B) Migration of $16 \mu \mathrm{g}$ of Factor X reduced with 2 -mercaptoethanol in $10 \%$ acrylamide, $0.1 \%$ SDS containing gels (C) Migration of $16 \mu \mathrm{g}$ Factor $\mathrm{X}$ in alkaline disc gel ( $\mathrm{pH}$ 8.9) containing 6\% arylamide. (D) Migration of $16 \mu \mathrm{g}$ of Factor $\mathrm{X}$ in isoelectric focusing gels with a pH gradient from 3 to 8 . The protein bands coincide with $\mathrm{pH} 4.8$ and 5.0. The anode is to the bottom in all the gel systems.
Neutralization of Factor $\mathrm{X}$ activity in plasmas of patients on warfarin therapy was also observed. Normal rabbit serum had no effect on Factor X activity present in these plasmas.

Radioiodinated Factor $\mathrm{X}$ was analyzed by SDSpolyacrylamide gel electrophoresis with and without reduction (Fig. 2). Bands of ${ }^{125}$ I were coincident only with the stained protein bands observed for Factor X, indicating that the ${ }^{125}$ I-ligand was structurally intact and that radiolabeled contaminants of different molecular weights were not present. Antigenic equivalence of labeled Factor $\mathrm{X}$ was analyzed by comparing the binding by antibody of four different mixtures of labeled and unlabeled Factor $\mathrm{X}$ at constant total concentration. The binding curves superimposed indicating that the affinity of the antibody for the Factor $\mathrm{X}$ was not altered by radioiodination. The

TABLE II

Amino Acid Composition of Human Factor X

\begin{tabular}{lrr}
\hline Amino acid & Residue No. & Residue No.* \\
\hline Lys & 31.6 & 31.1 \\
His & 7.8 & 8.9 \\
Arg & 23.2 & 22.1 \\
Asx & 48.8 & 45.8 \\
Thr & 33.2 & 35.3 \\
Ser & 22.8 & 26.7 \\
Glx & 64.8 & 61.5 \\
Pro & 18.8 & 19.6 \\
Gly & 40.4 & 38.8 \\
Ala & 27.2 & 26.2 \\
Val & 20.1 & 21.1 \\
Met & 6.4 & 6.3 \\
Ile & 15.6 & 15.6 \\
Leu & 29.0 & 29.4 \\
Tyr & 12.2 & 12.8 \\
Phe & 20.2 & 20.9 \\
& & \\
\hline
\end{tabular}

* Data from Di Scipio et al. (2). 


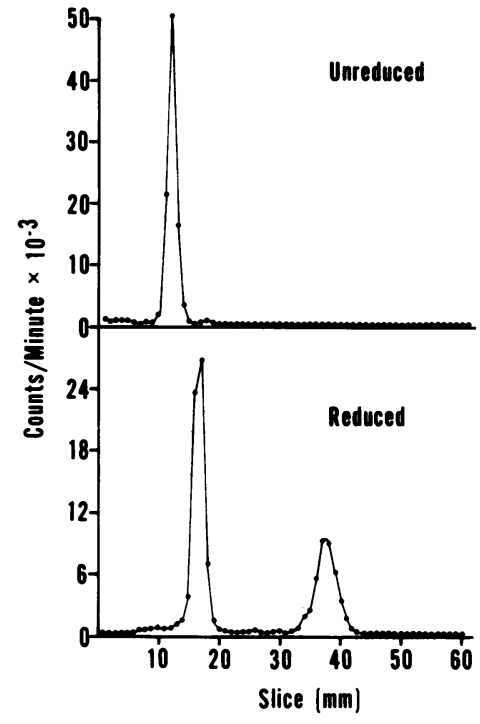

Figure 2 Electrophoretic migration of iodinated human Factor $\mathrm{X}$ on $10 \%$ acrylamide gels in SDS in the absence (top) and presence (bottom) of 2-mercaptoethanol. The anode and bottom of the gels are to the right.

authenticity of the labeled Factor $\mathrm{X}$ was further substantiated since analyses of nonradioactive iodinated Factor $\mathrm{X}$ behaved in a competitive inhibition radioimmunoassay identical to the unmodified protein. A representative antibody binding profile is shown in Fig. 3. At high antibody concentration $>95 \%$ of the labeled ligand was bound. The percent of ${ }^{125} \mathrm{I}$-Factor $\mathrm{X}$ bound decreased linearly with serial threefold dilutions of antibody and nonspecific binding was insignificant. For competitive inhibition assays antiserum sufficient to bind $60 \%$ of the ${ }^{125} \mathrm{I}-\mathrm{F}$ actor $\mathrm{X}$ was used.

The equilibrium competitive inhibition radioimmunoassay was used to compare purified Factor $\mathrm{X}$ with normal and abnormal plasma Factor $\mathrm{X}$. The specificity of the radioimmunoassay (Fig. 4) was supported by: $(a)$ complete inhibition by purified

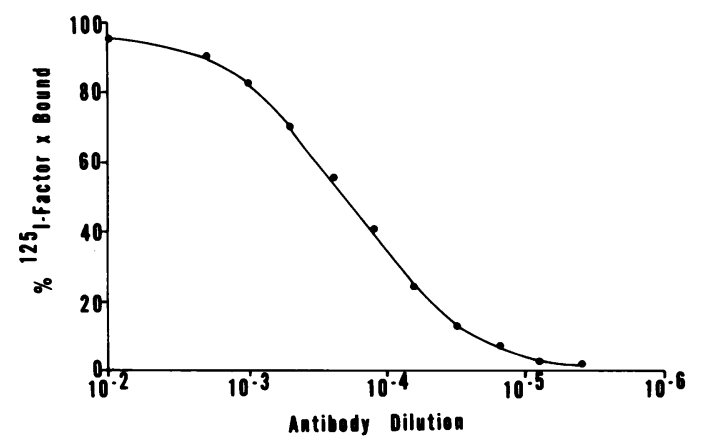

FIgURE 3 Binding of ${ }^{125} \mathrm{I}$-Factor $\mathrm{X}$ by dilutions of rabbit anti-Factor $X$ antigen. The ligand was added at $0.1 \mathrm{nM}$ concentration.

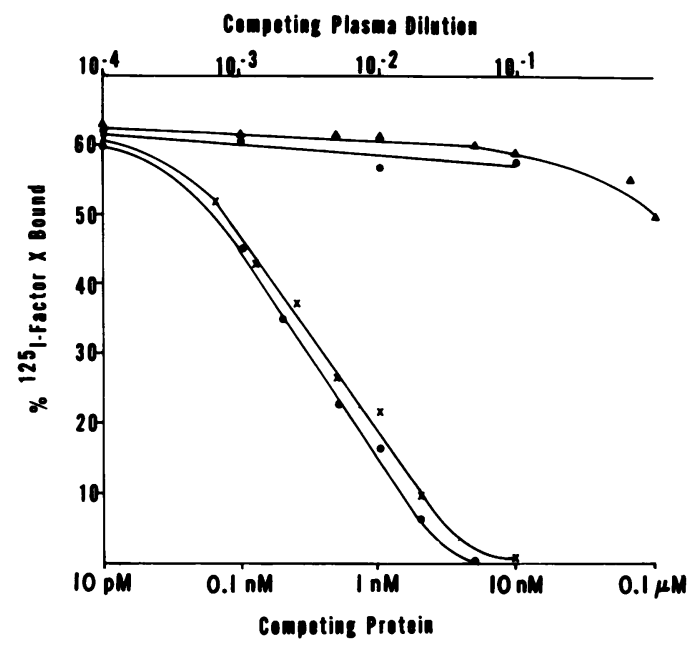

FIgURE 4 Equilibrium competitive inhibition of the binding of ${ }^{125} \mathrm{I}-\mathrm{F}$ actor $\mathrm{X}(0.1 \mathrm{nM}$ added) to anti-human Factor $\mathrm{X}$ $\left(5,000^{-1}\right.$ dilution) by purified human Factor $X(x)$, purified human prothrombin $(\boldsymbol{\Delta})$, normal human plasma pool $(\boldsymbol{\Theta})$, and normal bovine plasma $(O)$.

Factor $\mathrm{X}$ and normal pooled plasma; $(\boldsymbol{b})$ parallel slopes of inhibition by Factor $\mathrm{X}$ and normal pooled plasma; (c) absence of any inhibition by normal bovine plasma; and $(d)$ the absence of inhibition by purified prothrombin at a concentration at which Factor $\mathrm{X}$ produces complete inhibition. Slight inhibition by prothrombin was observed at a 1,000-fold molar excess and presumably represents contamination $(0.1 \%)$ with Factor X. Either these antisera do not contain antibodies or their affinity is too low for structurally homologous sequences of human prothrombin and bovine Factor $\mathrm{X}$ to exhibit significant binding. The range of sensitivity was from 6 to $300 \mathrm{ng}$ Factor $\mathrm{X} / \mathrm{ml}$.

Accuracy of measurement of Factor $\mathrm{X}$ in plasma was estimated by addition of serially increasing concentrations of purified Factor $\mathrm{X}$ to normal pooled human plasma. Using purified human Factor $\mathrm{X}$ as the standard: (a) the concentration of Factor X measured in plasma corresponded linearly to the amount of Factor $\mathrm{X}$ added to plasma and $(b)$ the Factor $\mathrm{X}$ concentration resulting from extrapolation of the linear regression to zero agreed with the assay value for the intrinsic plasma Factor X of $11.9 \mu \mathrm{g} / \mathrm{ml}$. These results indicated an analytic recovery of the amount of Factor $\mathrm{X}$ added to plasma and accurate quantitation of protein by radioimmunoassay.

The difference in concentration of Factor $\mathrm{X}$ in plasma by immunochemical $(11.9 \mu \mathrm{g} / \mathrm{ml})$ as contrasted to coagulant $(7.8 \mu \mathrm{g} / \mathrm{ml})$ assays is significant and reproducible. This prompted us to verify this observation by adsorption of Factor $\mathrm{X}$ to increasing amounts of barium citrate. The absorption of Factor $X$ coagulant activity and Factor $\mathrm{X}$ antigen from plasma is shown in 


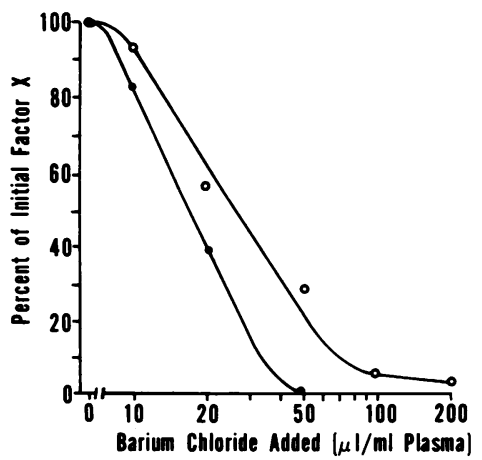

Figure 5 Differential adsorption of Factor $X$ coagulant activity (O) and Factor $\mathrm{X}$ antigen $(O)$ to barium citrate. The relative values of the initial Factor $\mathrm{X}$ activity and antigen are plotted vs. the volume of $1 \mathrm{M} \mathrm{BaCl}{ }_{2}$ added to $1 \mathrm{ml}$ of plasma.

Fig. 5. Complete removal of the coagulant activity occurred with the addition of $50 \mu \mathrm{l}$ of $1 \mathrm{M} \mathrm{BaCl} / \mathrm{ml}$ of citrated plasma. However, at this concentration, $\cong 29 \%$ of the Factor $X$ antigen remained unadsorbed. Residual coagulant activity was $<0.001 \mathrm{U} / \mathrm{ml}$ whereas there was $3.35 \mu \mathrm{g}$ Factor $\mathrm{X}$ antigen $/ \mathrm{ml}$. At considerably higher concentrations of added $\mathrm{BaCl}_{2}$, Factor $\mathrm{X}$ antigen lacking coagulant activity could be adsorbed, though a small amount (4\%) remained in plasma even with the highest amounts of added barium.

Immunochemical comparisons of purified Factor $\mathbf{X}$ and Factor $\mathrm{X}$ present in normal and abnormal plasma are depicted in Fig. 6. Each was capable of competing for the labeled Factor $X$ and completely inhibiting the reaction. Slopes of inhibition observed for each plasma were similar to the inhibition slope for the purified molecule, suggesting that this antiserum reacted equivalently with each. Relative to normal plasma the concentration required for $50 \%$ competitive inhibition was greater for all abnormal plasmas, indicating a decrease in the concentration of Factor $\mathrm{X}$ antigen as summarized in Table III. This is also depicted in Fig. 6 where the displacement of the competition curves are to the right of normal plasma. For only one abnormal plasma (No. 5) did the slope of inhibition differ from the standard; i.e., the slope differed from that of pooled normal plasma by $>2 \mathrm{SD}$. This plasma was from a very severe congenital Factor $\mathrm{X}$ deficiency requiring very high concentrations of plasma to permit detection of Factor $\mathrm{X}$ antigen. Although we cannot completely dismiss an effect by such a high protein concentration on assay equilibrium, the divergent slope suggests a structural defect that is reflected in an aberrant reaction of low affinity in the assay. Thus, with this single exception, this antiserum appears to react equivalently with normal Factor $X$ and most abnormal Factor $\mathrm{X}$ molecules derived from drug induction, acquired or congenital deficiency by

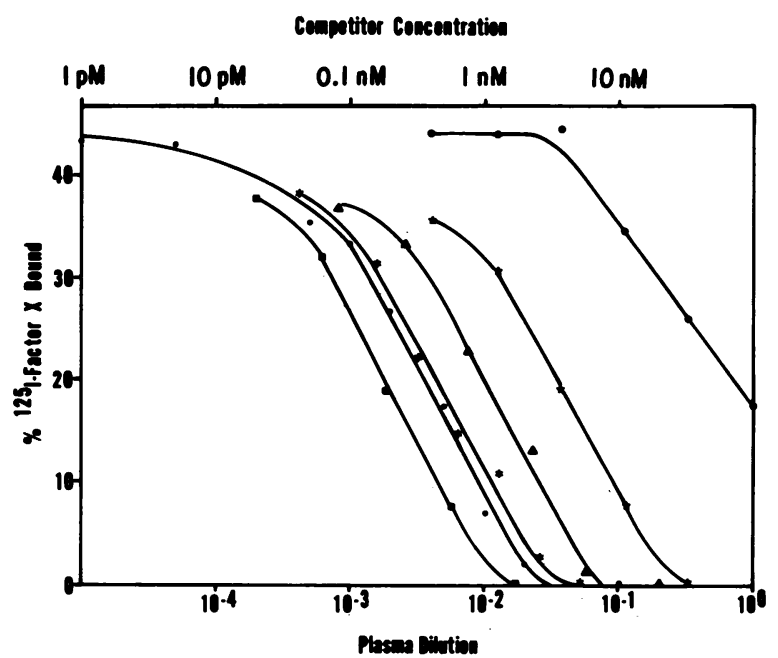

FIGURE 6 Equilibrium competitive inhibition of the binding of ${ }^{125} \mathrm{I}$-Factor $\mathrm{X}(0.05 \mathrm{nM}$ added) to anti-human Factor $\mathrm{X}$ $\left(12,000^{-1}\right)$ by purified human Factor $X(\Theta)$, and plasma from normal $(\square)$, warfarin treated $(*)$, acquired Factor $X$-deficient patient $9(\triangle)$, and hereditary Factor X-deficient $(\star, O)$ patients (Nos. 2 and 5).

reference to complete inhibition with sufficiently high plasma concentrations, and parallelism of inhibition slopes.

Comparisons of normal and abnormal Factor $\mathrm{X}$ antigen relative to coagulant activity generated by RVV and extrinsic activation are presented in Table IV. The mean concentration of normal plasma Factor $\mathrm{X}$ antigen was $11.9 \mu / \mathrm{ml}$ with $95 \%$ confidence limits of $7.09-16.69$ $\mu \mathrm{g} / \mathrm{ml}$. Plasmas from warfarin-treated patients averaged $4.9 \mu \mathrm{g} / \mathrm{ml}$ or $42 \%$ of that present in normal plasma. Eight plasmas from congenital Factor $\mathrm{X}$ coagulant activity-deficient patients were markedly deficient with a mean concentration of $0.36 \mu \mathrm{g} / \mathrm{ml}$. Two plasmas from patients diagnosed with amyloidosis and acquired Factor $X$ deficiency had a mean concentration of $3.5 \mu \mathrm{g}$ Factor $X$ antigen $/ \mathrm{ml}$. Factor $X$ coagulant activities

TABLE III

Antigenic Relationship and Expression of Human Factor X in the Plasma of Normal and Abnormal Patients*

\begin{tabular}{lcc}
\hline \multicolumn{1}{c}{ Plasma } & Inhibition slopet & CI $_{\text {so }}\left(\right.$ dil $\left.^{-1}\right)$ S \\
\hline Normal pool $(n=26)$ & -0.044 & 667 \\
Warfarin & -0.043 & 270 \\
Acquired deficient patient 9 & -0.046 & 118 \\
Congenital deficient patient 2 & -0.042 & 33.9 \\
Congenital deficient patient 5 & -0.053 & 1.7 \\
\hline
\end{tabular}

* Data obtained from Fig. 6.

I Expressed as percent bound per $\log _{10}$ antigen.

\$Inverse of the dilution requịred for $50 \%$ competitive inhibition. 
TABLE IV

Comparison of Normal and Abnormal Factor X Antigen with RVV and Extrinsic Pathway-Activated Activities*

\begin{tabular}{|c|c|c|c|c|c|c|}
\hline \multirow[b]{2}{*}{ Group } & \multirow[b]{2}{*}{$n$} & \multirow{2}{*}{$\begin{array}{c}\text { Factor } \mathrm{X} \\
\text { concentration }\end{array}$} & \multicolumn{2}{|c|}{ Factor $\mathrm{X}$ activity } & \multicolumn{2}{|c|}{ Factor $\mathrm{X}$ sp act } \\
\hline & & & RVV & Extrinsic & RVV & Extrinsic \\
\hline & & $\mu g / m l$ & \multicolumn{2}{|c|}{$U / m l$} & \multicolumn{2}{|c|}{ U/mg } \\
\hline Normal & 56 & $11.89 \pm 2.40$ & $1.00 \pm 0.24$ & $0.89 \pm 0.23$ & $83.91 \pm 11.51$ & $75.11 \pm 11.46$ \\
\hline Warfarin & 33 & $4.86 \pm 1.51$ & $0.16 \pm 0.08$ & $0.13 \pm 0.07$ & $34.06 \pm 15.17$ & $28.28 \pm 15.25$ \\
\hline Deficient & 8 & $0.36 \pm 0.26$ & $<0.008 \pm 0.006$ & $<0.03 \pm 0.03$ & ND $\ddagger$ & ND \\
\hline Amyloid & 2 & $3.50 \pm 2.33$ & $0.09 \pm 0.08$ & $0.06 \pm 0.04$ & $23.65 \pm 10.54$ & $16.85 \pm 0.92$ \\
\hline
\end{tabular}

* Values given as mean \pm standard deviation.

$\$$ Not determined.

measured by the two pathways gave similar results, although relative coagulant activity was slightly lower when activation was by the extrinsic pathway. The specific coagulant activities of Factor $X$ protein in the warfarin-treated group and in the amyloidosis patients were $\cong 30-35 \%$ of normal. This indicates that the decreased coagulant activity of these plasmas reflects

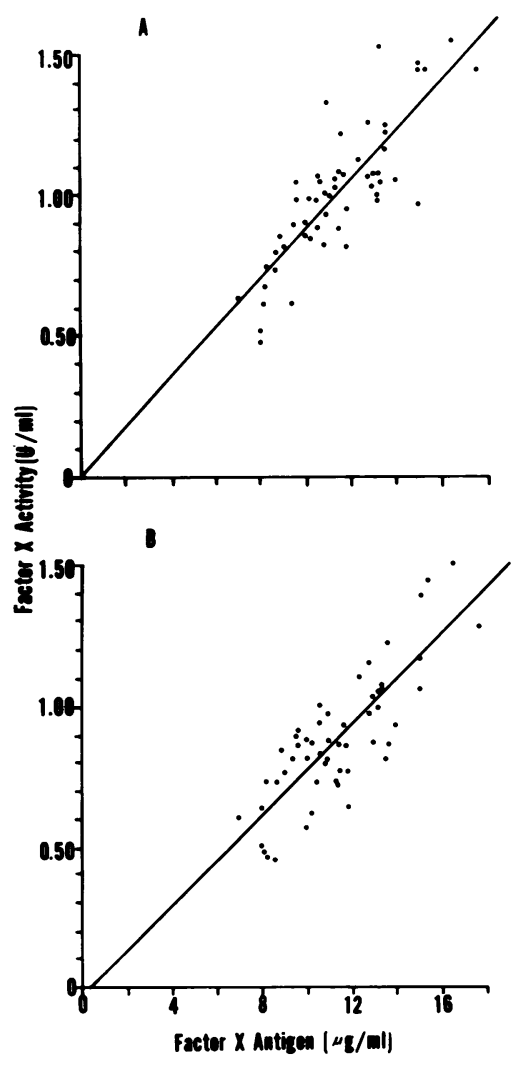

FIGURE 7 Correlation of Factor $\mathrm{X}$ activity with Factor $\mathrm{X}$ antigen in 56 normal plasmas, Factor $X$ procoagulant activity was measured using: (A) RVV activation $(r=0.83)$ and (B) the prothrombin time for the extrinsic pathway $(r=0.82)$. Factor $\mathrm{X}$ antigen was quantitated by radioimmunoassay. decreases in both the concentration of Factor $\mathrm{X}$ and the function of those molecules that are present. Because Factor $X$ coagulant activity cannot be accurately measured below $1 \%$ of normal in some of the congenitally deficient plasmas, specific activities of Factor X molecules present in these plasmas were not calculated.

The Factor X immunoassay was further characterized by correlating Factor $\mathrm{X}$ antigen with $\mathrm{Factor} X$ coagulant activity. Fig. 7A illustrates the results and depicts the linear regression analysis for 56 normal plasmas where the RVV-activated Factor $\mathrm{X}$ activity was plotted against the measured value of Factor $\mathrm{X}$ antigen. The correlation coefficient $(r)$ was $0.832(P<0.001)$ with the intercept passing through the origin. When Factor $\mathrm{X}$ activity was measured using the extrinsic path way of activation and plotted against Factor $\cdot \mathrm{X}$ antigen (Fig. 7B), the $r$ was $0.819(P<0.001)$. Observed variation appears to result predominantly from the Factor $\mathrm{X}$ coagulation assays where precision was $16.9 \%$.

Analysis of Factor $\mathrm{X}$ in plasmas from warfarintreated patients is shown in Fig. 8 and demonstrates the degree of concordance between Factor $\mathrm{X}$ antigen and Factor $\mathrm{X}$ activity by RVV activation (Fig. 8A) and extrinsic activation pathways (Fig. 8B). The $r$ for RVV activation and for extrinsic activation were 0.688 $(P<0.001)$ and $0.649(P<0.001)$, respectively. The regression lines had interceps at $\cong 1 \mu \mathrm{g} / \mathrm{ml}$ of Factor $X$ antigen instead of at the origin as for normal plasmas (Fig. 7).

Results for individuals with congenital and acquired Factor X deficiencies is summarized in Table V. In all congenitally deficient patients, only very limited quantities of Factor $\mathrm{X}$ antigen could be identified, e.g., including the severely deficient Factor X plasma (patient 5). Only modest differences in Factor $X$ activities (RVV, extrinsic, and intrinsic activation) were observed for most plasmas and parallel decreases in Factor $\mathrm{X}$ antigen and activities were observed. Patients $1,3,6$, and 8 had measurably higher levels 


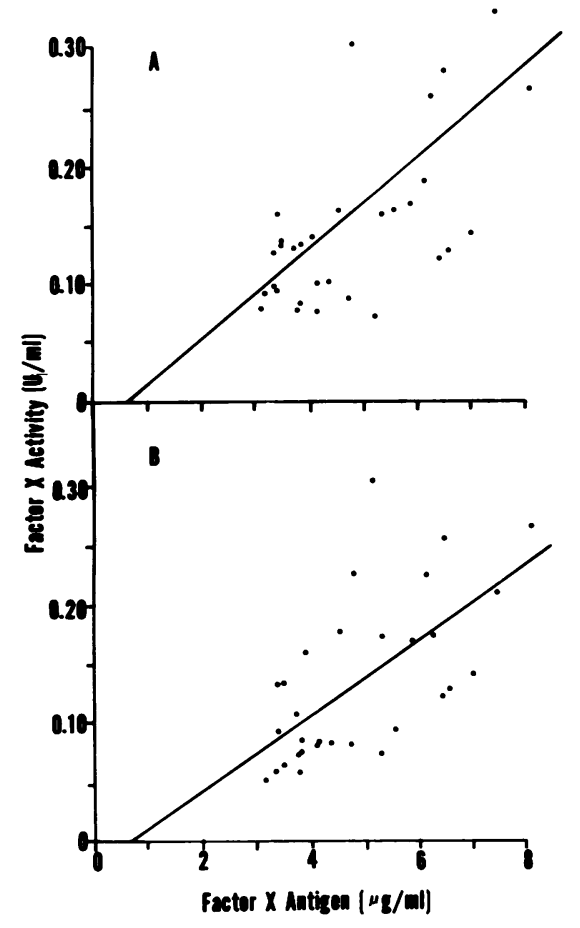

FIGURE 8 Correlation of Factor $\mathrm{X}$ activity with Factor $\mathrm{X}$ antigen in 33 plasmas from patients undergoing warfarin therapy. Factor $\mathrm{X}$ procoagulant activity was determined by activation by: (A) RVV $(r=0.69)$ and (B) the prothrombin time for the extrinsic pathway $(r=0.65)$. Factor $X$ antigen was quantitated by radioimmunoassay.

of Factor $\mathrm{X}$ activity by extrinsic activation relative to RVV or intrinsic activation pathways. Also, Factor X antigen was higher in patient 8 than other deficient cases, i.e., $\cong 8 \%$ of normal. Because this individual had clinical hemorrhagic problems requiring several transfusions, the Factor $\mathrm{X}$ antigen levels may not be accurately correlated with Factor $\mathrm{X}$ activity.

In the plasma of two patients with acquired deficiency and amyloidosis, Factor $\mathrm{X}$ coagulant activity was diminished relative to Factor $\mathrm{X}$ antigen, suggesting a significant functional abnormality which was relatively greater than that observed for congenitally deficient plasmas. Mixing experiments did not demonstrate a coagulation inhibitor in these plasmas, and we conclude on the basis of current evidence that these may also be a defective Factor $\mathrm{X}$ molecule in this type of amyloidosis.

\section{DISCUSSION}

Isolation of the proteins of the coagulation pathways has made possible not only biochemical characterization but also immunochemical analyses of concentration, molecular heterogeneity, and specific functional activity of these proteins in plasma (33-39) as well as specific assays of the activated enzyme (40) and proteolytic degradation products $(41,42)$. The molecular biology of Factor $\mathrm{X}$ is inordinately complex as evidenced by its multiple interactions; and precise analyses of molecular mass are required for studies of the functional biology of this molecule in thrombotic and hemostatic diseases. The present study has addressed the quantitative analysis of Factor $\mathrm{X}$ protein in plasma by reference to its antigenic properties and by correlation with Factor $\mathrm{X}$ coagulant activity.

Cohn fraction III can be used as a readily available source for the isolation of highly purified Factor $\mathrm{X}$ required for immunochemical standardization and analyses. The physicochemical characteristics are in reasonable agreement with other reports (2-6), indicating an estimated mol wt of 64,000 for the intact molecule and 46,000 and 17,000 , respectively for the heavy and light chains. The $8.5 \%$ higher estimate of mass than that of DiScipio et al. (2) may reflect the aberrantly higher molecular weight estimates that occur with SDS acrylamide gel analysis of glycoproteins (43). Of interest and first described here is the observation of two forms of human Factor $\mathrm{X}$ that were resolved by isoelectric focusing. These

TABLE V

Factor X Antigen and Activities in Plasmas from Congenital and Acquired Factor $X$-Deficient Patients

\begin{tabular}{|c|c|c|c|c|}
\hline \multirow[b]{2}{*}{ Group } & \multirow[b]{2}{*}{$\begin{array}{c}\text { Factor } \mathrm{X} \\
\text { antigen }\end{array}$} & \multicolumn{3}{|c|}{ Factor $\mathrm{X}$ activity } \\
\hline & & RVV & $\begin{array}{l}\text { Prothrombin } \\
\text { time }\end{array}$ & $\begin{array}{c}\text { Kaolin- } \\
\text { cephalin } \\
\text { clotting } \\
\text { time }\end{array}$ \\
\hline & $\mu g / m l^{*}$ & $U / m l$ & $\mathrm{U} / \mathrm{ml}$ & $s$ \\
\hline \multicolumn{5}{|c|}{$\begin{array}{r}\text { Congenital } \\
\text { deficient }\end{array}$} \\
\hline 1 & 0.28 & 0.01 & 0.05 & 310 \\
\hline 2 & 0.30 & $<0.01$ & 0.01 & 318 \\
\hline 3 & 0.56 & 0.01 & 0.09 & 262 \\
\hline 4 & 0.33 & $<0.01$ & $<0.01$ & 401 \\
\hline 5 & 0.03 & $<0.01$ & $<0.01$ & 384 \\
\hline 6 & 0.25 & 0.01 & 0.07 & 352 \\
\hline 7 & 0.24 & 0.02 & $<0.01$ & 328 \\
\hline 8 & 0.89 & 0.01 & 0.03 & 270 \\
\hline \multicolumn{5}{|c|}{$\begin{array}{l}\text { Acquired } \\
\text { deficient }\end{array}$} \\
\hline 9 & 1.85 & 0.03 & 0.03 & 215 \\
\hline 10 & 5.15 & 0.16 & 0.09 & 157 \\
\hline Normal & 11.89 & 1.00 & 0.89 & 112 \\
\hline
\end{tabular}

* Determined by radioimmunoassay.

† Activities were measured by activation with RVV, the extrinsic pathway using the prothrombin time, and the intrinsic pathway using the kaolin-cephalin clotting time. 
species may be analogous to the two forms of bovine Factor X $(31,32)$.

Our radioimmunoassay for human Factor $\mathrm{X}$ was characterized by fulfilling the requirements for specificity, conservation of the native protein conformation of the iodinated ligand, and demonstrating analytical recovery of Factor $\mathrm{X}$ added back to plasma. Specificity of the assay was indicated by the complete inhibition of the assay by both purified Factor $X$ and normal human plasma, and the inability of purified human prothrombin and normal bovine plasma to inhibit the reaction. The range of assay was $6-300 \mathrm{ng}$ Factor $\mathrm{X}$ antigen $/ \mathrm{ml}$, and the precision was indicated by a coefficient of variation of $1-4 \%$ within assays and $2.9-10.6 \%$ between assays.

Determination of Factor $\mathrm{X}$ concentration by direct immunochemical techniques gave higher values $(11.9 \mu \mathrm{g} / \mathrm{ml}$ ) than those indirectly measured using coagulant assays $(7.8 \mu \mathrm{g} / \mathrm{ml})$. Our results on the differential removal of Factor $X$ coagulant activity and Factor $\mathrm{X}$ antigen by barium citrate suggests the existence of a subpopulation of inactive or nonactivatable Factor X molecules with low affinity for barium citrate present in normal plasma. The radioimmunoassays showed no cross-reaction with other plasma proteins and very low levels of Factor $\mathrm{X}$ antigen were measured in plasmas of congenitally Factor X-deficient patients indicating that the concentration of Factor $X$ antigen describes the total Factor $X$ (active and nonactive) present in normal plasma.

The immunochemical analysis of normal as well as abnormal plasma Factor $\mathrm{X}$ indicated that these proteins appeared antigenically identical because they were capable of complete inhibition and the inhibition slopes were similar. Antigenic identity observed between purified Factor $\mathrm{X}$ and normal human plasma was expected, but has only been reported by far less critical and discriminating immunodiffusion techniques $(9,12,13)$. The finding that Factor $\mathrm{X}$ present in the plasma of patients on warfarin therapy appeared immunochemically identical with normal Factor $X$ agrees with previous reports for bovine Factor $\mathrm{X}$ and decarboxy Factor X (13), and implied for human Factor $X$ by immunodiffusion (9) and antibody neutralization $(8,12)$. In those studies on the bovine molecules (13) and in the present study on human Factor X, antisera were generated in rabbits using highly purified and well-characterized Factor $\mathrm{X}$, mitigating the possible contamination by other plasma proteins.

Seven of eight congenital and both acquired Factor Xdeficient plasma appeared antigenically indistinguishable from normal as judged by completely inhibiting the radioimmunoassay with similar inhibition slopes as seen with purified Factor $\mathrm{X}$ and normal plasma. Only one patient (No. 5) showed a divergent inhibition slope indicating possible antigenic modulation. Because we were unable to completely inhibit the reaction with neat plasma, we could not determine whether or not this Factor $\mathrm{X}$ was missing antigenic sites, contained all the sites but exposure was hindered, or sites were sterically altered to produce a decreased affinity for the antibody. All deficient plasmas in this study showed a significant decrease in Factor $\mathrm{X}$ antigen as well as all Factor X coagulant activities. This differed from the studies of Denson et al. (7) where distinct differences were observed in either the level of antigen or in one of the three Factor $\mathrm{X}$ activities as measured by RVV, extrinsic, or intrinsic activation. Differences in Factor $\mathrm{X}$ antigen concentration might reflect the specificity of the antisera generated by these workers or the relative insensitivity of antibody neutralization or both. The Factor $\mathrm{X}$ radioimmunoassay offers a more objective immunochemical and highly versatile method to obtaining plasma concentrations of this molecule independent of activity. Differences noted among the deficient plasmas when Factor $\mathrm{X}$ was activated by three different pathways are less well understood. Our data would suggest that a similar genetic defect occurred among these patients with conservation of antigenic structure. These events appeared to influence both the concentration of Factor $\mathrm{X}$ and the activation of this molecule by the three pathways. However, Girolami et al. (11) have described an isolated population within which occurs an abnormal Factor X, Factor X Friuli, which is very poorly and slowly activated by the extrinsic and intrinsic pathways although it is activated by RVV in a normal fashion.

Studies on other coagulation proteins, especially Factors VIII and IX, indicated that for most plasmas deficient in activity there were severe decreases in antigen levels (35-38). However, in some cases, significant levels of antigen were observed in plasmas deficient in activity $(35,38)$. These data would suggest a genetic heterogeneity among the clotting proteins. The presence of high levels of Factor $X$ antigen in plasma deficient in Factor $\mathrm{X}$ activity was observed in the acquired Factor X-deficient plasma and might well be detected in congenitally deficient patients with a larger sampling pool.

Factor $\mathrm{X}$ antigen in the plasmas of warfarin-treated patients was decreased to $\cong 42 \%$ and the Factor $X$ activity reduced to $13-16 \%$ of that seen for normals. This indicated a two- to threefold reduction in specific activity of warfarin X. Antibody neutralization experiments have suggested the presence of higher Factor $X$ levels in similar patients relative to their levels of Factor $X$ activity $(8,9)$. The Factor $X$ radioimmunoassay not only has confirmed this finding but has quantitated the reduction in concentration to about half that of normal plasma. The reduced levels of 
Factor $\mathrm{X}$ coagulant activity are probably the result of the blocking effect warfarin has on the post translational vitamin K-dependent carboxylation of Factor X (44), and the decreased concentration of this molecule may reflect increased catabolic rate or decreased secretion of the abnormal protein. Similar findings have been reported for Factor IX $(35,45)$. The regression lines from plot of activity vs. antigen determinations in these patients (Fig. 8) was seen to intersect at $\cong 1 \mu \mathrm{g} / \mathrm{ml}$ of Factor $X$. This might suggest the presence of a competitive inhibitor of Factor $\mathrm{X}$ which would interfere with the activation of normal Factor $\mathrm{X}$ molecules present in plasma. Similar findings support the kinetic studies of Hemker and Muller (46) who reported that the protein induced by vitamin $\mathrm{K}$ absence inhibition showed a rate-limiting step at Factor $\mathrm{X}$ and the inhibition appeared to be competitive in nature.

In the two patients with amyloidosis and acquired Factor X deficiency, we observed only a modest decrease of Factor $\mathrm{X}$ antigen but markedly depressed Factor $\mathrm{X}$ activity indicative of a decrease in the specific activity of the Factor $X$ present in their plasmas. Removal of endogenous Factor $\mathrm{X}$ of these patients as well as exogenous normal Factor $\mathrm{X}$ from plasma appears to be mediated by the amyloid fibrils deposited throughout the vasculature $(18,19)$. Immunologic identity between the amyloid-associated Factor $\mathrm{X}$ protein and normal Factor $\mathrm{X}$ are consistent with this notion. This suggests a subset of abnormal Factor $\mathrm{X}$ molecules whose expression is enhanced in these patients by the removal of normal Factor $\mathrm{X}$ molecules. However, the activity defect observed for Factor $\mathrm{X}$ in these patients may be a secondary effect and this will require further investigation.

\section{ACKNOWLEDGMENTS}

The authors wish to thank Dr. D. Aronson for the gift of a sample of anti-Factor $\mathrm{X}$ antiserum; Doctors J. Graham, Y. Sultan, A. Bloom, B. Furie, S. Lemkin, H. L. Nossel, J. Baker, and Ms. L. De la Pointe for the generous provision of abnormal plasmas; Dr. M. Hrinda, Armour Pharmaceutical Company for Cohn fraction III; V. Byers for excellent technical assistance; and M. Gortmaker and S. Garland for preparation of the manuscript.

This work was supported by research grant HL-16411 and training grant HL-07195 from the U. S. Public Health Service.

\section{REFERENCES}

1. Suttie, J. W., and C. M. Jackson. 1977. Prothrombin structure, activation, and biosynthesis. Physiol. Rev. 57: $1-70$.

2. DiScipio, R. G., M. A. Hermodsen, S. G. Yates, and E. W. Davie. 1977. A comparison of human prothrombin, Factor IX (Christmas Factor), Factor X (Stuart Factor), and protein S. Biochemistry. 16: 698-706.

3. Aronson, D. L., A. J. Mustafa, and J. F. Mushinski. 1969. Purification of human Factor $\mathrm{X}$ and comparison of peptide maps of human Factor $\mathrm{X}$ and prothrombin. Biochim. Biophys. Acta. 188: 25-30.

4. Kosow, D. P. 1976. Purification and activation of human Factor X: cooperative effect of $\mathrm{Ca}^{++}$on the activation reaction. Thromb. Res. 9: 565-573.

5. Vician, L., and G. H. Tishkoff. 1976. Purification of human blood clotting Factor $\mathrm{X}$ by blue dextran agarose affinity chromatography. Biochim. Biophys. Acta. 434: 199-208.

6. Miletich, J. P., C. M. Jackson, and P. W. Majerus. 1978. Properties of the Factor $\mathrm{Xa}$ binding site on human platelets. J. Biol. Chem. 253: 6908-6916.

7. Denson, K. W. E., A. Lurie, F. DeCataldo, and P. M. Mannucci. 1970. The Factor X defect: recognition of abnormal forms of Factor X. Br.J. Haematol. 18: 317-327.

8. Denson, K. W. E. 1971. The levels of Factors II, VII, IX and $\mathrm{X}$ by antibody neutralization techniques in the plasma of patients receiving phenindione therapy. $\mathrm{Br}$. J. Haematol. 20: 643-648.

9. Prydz, H., and A. Gladhaug. 1971. Factor X. Immunological studies. Thromb. Diath. Haemorrh. 25: 157-165.

10. Chodosh, B. T., S. S. Shapiro, and D. L. Aronson. 1969. Immunologic investigation of two patients with congenital Factor X deficiency. Clin. Res. 17: 599. (Abstr.)

11. Girolami, A., A. Brunetti, G. Bareggi, and G. Cella. 1974. Abnormal Factor X (Factor X Friuli) coagulation disorder. The heterozygote population. Acta Haematol. (Basel). 51: 40-50.

12. Gaudernack, G., A. G. Berre, B. $\emptyset$ sterud, and H. Prydz. 1974. Immunological studies on the blood coagulation Factor X and its warfarin-induced precursor. Thromb. Diath. Haemorrh. 31: 40-51.

13. Lindhout, M. J., B. H. M. Kop-Klaassen, J. M. M. Kop, and H. C. Hemker. 1978. Purification and properties of the phenprocoumon-induced decarboxyfactor $\mathrm{X}$ from bovine plasma. A comparison to normal Factor $\mathrm{X}$. Biochem. Biophys. Acta. 533: 302-317.

14. Davis, A. D., R. F. Murphy, and D. T. Elmore. 1974. A radioimmunoassay of bovine Factor X. Biochem. Soc. Trans. 2: 738-739.

15. Arai, H., and Y. Takeda. 1977. Properties and radioimmunoassay of canine Factor X. Thromb. Res. 11: 57-66.

16. Graham, J. B., E. M. Barrow, and C. Hougie. 1957. Stuart clotting defect. II. Genetic aspects of a "new" hemorrhagic state. J. Clin. Invest. 36: 497-503.

17. Krause, J. R. 1977. Acquired Factor $X$ deficiency and amyloidosis. Am. J. Clin. Pathol. 67: 170-173.

18. Furie, B., E. Greene, and B. C. Furie. 1977. Syndrome of acquired Factor $\mathrm{X}$ deficiency and systemic amyloidosis. In vivo studies of the metabolic fate of Factor X. N. Engl. J. Med. 297: 81-85.

19. Triplett, D. A., N. U. Bang, C. S. Harms, M. D. Benson, and J. P. Miletich. 1977. Mechanisms of acquired Factor X deficiency in primary amyloidosis. Blood. 50: 285. (Abstr.)

20. Schmer, G. 1972. The purification of bovine thrombin by affinity chromatography on benzamidine-agarose. HoppeSeyler's Z. Physiol. Chem. 353: 810-814.

21. Kimmel, J. R. 1969. Guanidination of proteins. Methods Enzymol. 11: 584-589.

22. Bachmann, F., F. Duckert, and F. Koller. 1958. The Stuart-Prower factor assay and its clinical significance. Thromb. Diath. Haemorrh. 2: 24-38.

23. Denson, K. W. E., and R. Biggs. 1976. Laboratory diagnosis, tests of clotting function and their standardization. In Human Blood Coagulation, Haemostasis and Thrombosis. R. Biggs, editor. Blackwell Scientific Publications, Ltd., Oxford. 2nd edition. 310-364. 
24. Davis, B. J. 1964. Disc electrophoresis. II. Method and application to human serum proteins. Ann. N. Y. Acad. Sci. 121: 404-427.

25. Weber, K., and M. Osborn. 1969. The reliability of molecular weight determinations by dodecyl sulfatepolyacrylamide gel electrophoresis. J. Biol. Chem. 244: 4406-4412.

26. Laemmli, U. K. 1970. Cleavage of structural proteins during the assembly of the heat of bacteriophage T4. Nature (Lond.). 227: 680-685.

27. Righetti, P. G., and J. W. Drysdale. 1976. In Isoelectric Focusing. North Holland Publishing Co., Amsterdam. $440-447$.

28. Reisner, A. H., P. Nemes, and C. Bucholtz. 1975. The use of Coomassie brilliant blue G250 perchloric acid solution for staining in electrophoresis and isoelectric focusing on polyacrylamide gels. Anal. Biochem. 64: $509-516$

29. McConahey, P. J., and F. J. Dixon. 1966. A method of trace iodination of proteins for immunologic studies. Int. Arch. Allergy Appl. Immunol. 29: 185-189.

30. Rodbard, D. 1974. Statistical quality control and routine data processing for radioimmunoassays and immunoradiometric assays. Clin. Chem. 20: $1255-1270$.

31. Jackson, C. M., and D. J. Hanahan. 1968. Studies on bovine Factor X. II. Observations on some alterations in zone electrophoretic and chromatographic behavior occurring during purification. Biochemistry. 7: 4506-4517.

32. Fujikawa, K., M. E. Legaz, and E. W. Davie. 1972. Bovine Factors $\mathrm{X}_{1}$ and $\mathrm{X}_{2}$ (Stuart Factor), isolation and characterization. Biochemistry. 11: 4882-4891.

33. Zimmerman, T. S., J. Roberts, and T. S. Edgington. 1975. Factor VIII-related antigen: multiple molecular forms in human plasma. Proc. Natl. Acad. Sci. U. S. A. 72: 5121-5125.

34. Ruggeri, Z. M., P. M. Mannucci, S. L. Jeffcoate, and G. I. C. Ingram. 1976. Immunoradiometric assay of Factor VIII related antigen, with observations in 32 patients with von Willebrand's disease. Br. J. Haematol. 33: $221-232$

35. Thompson, A. R. 1977. Factor IX antigen by radioimmunoassay. Abnormal Factor IX protein in patients on warfarin therapy and with hemophilia B. J. Clin. Invest. 59: $900-910$.

36. Yang, H. C. 1978. Immunologic studies of Factor IX (Christmas Factor) II. Immunoradiometric assay of Factor IX antigen. Br. J. Haematol. 39: 215-224.

37. Peake, J. R., and A. L. Bloom. 1978. Immunoradiometric assay of procoagulant Factor VIII antigen in plasma and serum and its reduction in haemophilia. Preliminary studies on adult and fetal blood. Lancet. I: 473-475.

38. Lazarchick, J., and L. W. Hoyer. 1978. Immunoradiometric measurement of the Factor VIII procoagulant antigen. J. Clin. Invest. 62: 1048-1052.

39. I.ox, C. D., G. H. Strohm, and J. J. Corrigan, Jr. 1978. Radioimmunoassay of human prothrombin - the quantitation of plasma Factor II antigen. Am. J. Hematol. 4: 261-267.

40. Shuman, M. A., and P. W. Majerus. 1976. The measurement of thrombin in clotting blood by radioimmunoassay. J. Clin. Invest. 58: 1249-1258.

41. Plow, E. F., C. Hougie, and T. S. Edgington. 1971. Neoantigenic expressions engendered by plasmin cleavage of fibrinogen. J. Immunol. 107: 1496-1500.

42. Plow, E. F., and T. S. Edgington. 1973. Immunobiology of fibrinogen. Emergence of neoantigenic expressions during physiologic cleavage in vitro and in vivo. J. Clin. Invest. 52: 273-282.

43. Segrest, J. P., and R. L. Jackson. 1972. Molecular weight determinations of glycoproteins by polyacrylamide gel electrophoresis in sodium dodecyl sulfate. Methods Enzymol. 28: 54-63.

44. Jackson, C. M., and J. W. Suttie. 1977. Recent developments in understanding the mechanism of vitamin $\mathrm{K}$ and vitamin K-antagonist drug action and the consequences of vitamin $\mathrm{K}$ action in blood coagulation. Prog. Hematol. 10: $333-359$.

45. Orstavik, K. H., and K. Laake. 1978. Factor IX in warfarin treated patients. Thromb. Res. 13: 207-218.

46. Hemker, H. C., and A. D. Muller. 1968. Kinetic aspects of the interaction of blood-clotting enzymes. VI. Localization of the site of blood coagulation inhibition by the protein induced by vitamin K absence (PIVKA). Thromb. Diath. Haemorrh. 20: 78-87. 